\title{
Impact of Tenofovir/Lamivudine/Dolutegravir (TId) on the Health-Related Quality of Life and Clinical Outcomes of HIV/AIDS Patients at a Tertiary Health Facility in Niger State
}

Danjuma Umar ( $\sim$ rxdanjumar@gmail.com )

Ahmadu Bello University

\section{Bala Waziri}

Ibrahim Badamasi Babangida Specialist Hospital

Umar Ndagi

Ibrahim Badamasi Babangida Specialist Hospital

Shafiu Mohammed

Ahmadu Bello University

Ndagi Usman

Ahmadu Bello University

Hauwa Abubakar-Muhammad

Federal Medical Centre Bida

\section{Research Article}

Keywords: TLD, HIV/AIDS, HRQoL, Clinical outcomes, Nigeria

Posted Date: December 16th, 2020

DOI: https://doi.org/10.21203/rs.3.rs-127277/v1

License: (c) (1) This work is licensed under a Creative Commons Attribution 4.0 International License.

Read Full License 


\section{Abstract}

Background: Human Immuno-deficiency Virus (HIV) remains a major global public health issue. However, it is now considered a chronic infection which can be managed with new, well-tolerated and efficacious ARVs. The aim of the study was to evaluate the effect of Tenofovir/Lamivudine/Dolutrgravir (TLD) on the HRQoL and viral suppression over a short period.

Method: The study was prospective, with a time frame of three (3) months. HRQoL was measured using a disease specific HIV/AID Targeted Quality of Life (HAT-QoL) tool and the clinical outcomes focused on viral load using structured data collection tool.

Results: Most of the participants were female (62.1\%), currently married $63.2 \%$ and no co-morbidity, mean age $43 \pm S D$ (range 21-77years). There was a statistically significant improvement in HRQoL scores across all domain after 3 months of transitioning to TLD. While 8 of the 9 domains namely; overall functions, life satisfaction, health worries, financial worries, medication worries, HIV mastery, Disclosure worries, Provider trust, $(p<0.001)$ sexual function $(p=0.015)$. Improvement was also seen in viral suppression ( $p$ $<0.001)$.

Using multiple linear regression analysis, predictors for overall HRQol scores include female gender ( $\mathbb{\nabla}=$ $3.59,95 \% \mathrm{Cl} 1.30-5.78, \mathrm{p}=0.002)$, older age, $>65$ years $(\mathbb{\nabla}=4.12,95 \% \mathrm{Cl}-1.42,9.67 \mathrm{p}=0.08)$, living with family

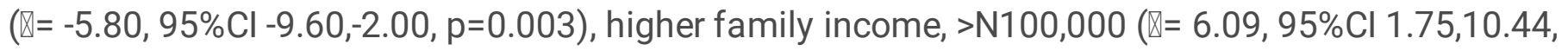

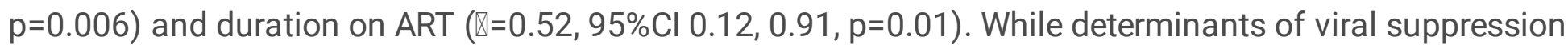
using multi-variant logistic regression analysis revealed living with family $(A O R=18.03,95 \% \mathrm{Cl} 3.32-97.85$, $p<0.001$ ), Primary education ( $A O R=0.16,965 \% \mathrm{Cl} 0.029,0.93, P=0.041$ ), being employed ( $A O R=0.16$, $95 \% \mathrm{Cl} 0.028,0.91, \mathrm{P}=0.008)$, income and baseline viral load $(\mathrm{AOR}=0.53,95 \% \mathrm{Cl} 0.44,0.69, \mathrm{p}<0.001)$. However, living with family is major determinant of viral suppression.

Conclusion: TLD help improved health related quality of life among HIV infected individual and essential in rapid viral suppression.

\section{Background}

Human Immuno-deficiency Virus (HIV) remains a major global public health issue, having claimed more than 35 million lives so far $(1,2)$. At the end of 2019 , there were approximately 38 million people living with HIV with 1.7 million people becoming newly infected in 2019 globally (3-6) Without treatment, average survival time after infection with HIV is estimated to be 9 to 11 years, depending on the HIV subtype (7). However, potent combinations of antiretroviral drugs have dramatically altered the natural progression of HIV infection and significantly improved patients' quality of life (8). As a result, the number of new Acquired Immuno Deficiency Syndrome (AIDS)-related opportunistic infections and deaths has declined (9). Consequently, the use of HAART has shifted HIV infection from being a terminal illness to a long-term manageable chronic infection, and many people living with HIV infected individuals can have a life expectancy marginally close to that of HIV uninfected individuals(7). However, people living with HIV 
(PLWH) continues to face a variety of health-related challenges, which can affect many aspects of their quality of life. These include among other factors social, psychological, functional, occupational and physical well-being (10).

Viral load measure of plasma HIV RNA (viral load) estimates the amount of circulating virus in the blood. This has been proven to correlate with prognosis, with a high viral load predicting faster disease progression (7). Conversely, a reduction in viral load after commencement of antiviral therapy is associated with clinical benefit $(8,9)$.

In 2019,WHO recommended Dolutegravir (DTG) based regimen as the most preferred regimen for adults and adolescents (1). DTG is an integrase enzyme inhibitor and when combined with 2 other ARVs in a single fixed-dose combination pill, is considered to be among the best current treatments for HIV (1). Its availability has previously been limited due to high cost. However; following the availability of a generic fixed-dose combination of Tenofovir/Lamivudine/Dolutegravir (TLD) to an average price of US\$75 (N 26,250 ) per patient per year, DTG-containing ARV regimens is now affordable for many low-and middleincome countries(1). The quest for a safe, efficacious and cost-effective regimen is responsible for continuous evolution of ART. Dolutegravir regimen is the newest regimen recommended by the Nigeria Federal Ministry of Health as the preferred first line therapy $(1,2)$. It was formerly a substitute for patients that cannot tolerate efavirenze based regimen. In comparison to Efavirenze (EFV), the current widely used first line drug, DTG is found to be more efficacious, durable, tolerable, higher bioavailability, lower pill burden, and potential for fewer side effects (1). DTG also had better viral suppression efficacy than other integrase inhibitors (7). Regimens containing DTG and EFV 600mg were comparable with respect to mortality, AIDS-defining illnesses and occurrence of serious adverse events (1).

HRQoL measures are becoming an integral part of patient follow-up, providing valuable feedback, from the patients' perspective, about the disease and associated interventions $(10,11)$. HRQoL assessment in HIV/AIDS takes into account the impact of the infection and antiretroviral therapy (ART) on an individual's physical, psychological and social wellbeing, as reported by the patient. HRQoL measures are important as indicators of the effectiveness of HIV/AIDS treatment and care programmes. Measurements of HRQoL can be incorporated into models that inform economic evaluation of HIV/AIDS treatment services, making them pivotal in resource allocation decisions. Such assessments can also be useful in identifying factors associated with HRQoL among people living with HIV, thereby informing public health decisions on specific impact mitigation and support interventions that may be required to maximize HRQoL (12). Although in Nigeria there are studies that have evaluated the HRQoL in patients on non-DTGbased regimen (13-17), a huge gap in knowledge exist in the outcomes of patients on DTG-based regimen. Therefore, the aim of this study was to evaluate the impact of DTG-based regimen on the HRQoL among HIV/AIDS patients.

\section{Method}

Study Design 
A prospective approach was used in this study. Participants were recruited consecutively between July 2019 to September 2019 for the baseline parameters and subsequently followed up to December 2019.

\section{Study setting}

The study was conducted at Ibrahim Badamasi Babangida Hospital, (IBBSH). The hospital is a major referral centre in Niger state, located about $10 \mathrm{~km}$ from Paiko town. It has a functional ART clinic with an active ART team that comprises medical doctors, pharmacists, and triad nurses caring for approximately 700 HIV-infected patients.

\section{Ethical consideration}

Ethical approval was sought from the IBBSH human research and ethics committee. Clearance certificate number M201902. All participants gave written informed consent prior to enrollment into the study, in addition to maintaining confidentiality of patients throughout the study.

\section{Study Participants and Sample size}

A total of 286 participants were involved in the study. A minimum of 249 participants was estimated to be sufficient in representing the population of about 700 patients at $5 \%$ error margin and $95 \%$ confidence interval using Raosoft@ online sample size calculator with an addition of $15 \%$ for response rate (18). The study involved all the HIV-infected clients attending the clinic, meeting the eligibility criteria and that consented to participate in the study.

\section{Eligibility criteria}

i. Participants must be on TLD regimen.

ii. Participants must be aged $18-60$ years or older.

iii. The patient most have commenced the ART for at least 6 months.

\section{Instruments}

Information on demography, medical history and the clinical outcomes was obtained from patients' hospital folders and fill in a well-structured data collection form. The HRQoL was measured using the HIV/AIDS-Targeted Quality of Life (HAT-QoL) developed and validated by Homes and Shea (19). It consists of 34 item stems in nine domains: overall function, health worries, life satisfaction, disclosure worries, financial worries, medication concerns, provider trust, HIV mastery and sexual function. This tool has been successfully adopted in Nigeria by Oparah and colleague (13). Similarly, Biambo et al applied it in a study in Sokoto, North-western, Nigeria(14). Reponses from the HAT-QoL instrument was transformed to numerical values for each dimension using the guide provided with the instrument $(12,13,15)$.

Positively worded questions were scored 5 to 1 for "All of the times" to "None of the time" responses were respectively. While negatively worded ones, "All of the time" to "None of the time" responses was scored 1 
to 5 , respectively. The final dimension score was a linear scale, ranging $0-100$, where 0 is the worst score possible and 100 being the best score possible $(13,14)$.

\section{Data Collection Procedure}

Schedule method was used for participants with no formal education while the literates were served the questionnaire and guided as appropriate. Using systematic sampling techniques eligible clients were requested to participate taking a maximum of 12 clients per clinic visit, 2 clinics per week over 3 months period until the calculated sample size was achieved. The participants' socio-demographic characteristics, clinical, medication data was obtained from the medical records department from their folders using a specifically designed data collection form. Data on patients' HRQoL was gathered using the HIV/AIDS- Targeted Quality of Life (HAT-QoL) instrument.

\section{Data analysis and Presentation}

Descriptive analysis was used to summarize the socio-demographics and HIV-related characteristics and HRQoL profiles of the participants. HRQoL scores of patients with different socio-demographic and clinical characteristics were compared using students't-test. Factors associated with or predicting patients' HRQoL scores and viral suppression were identified using correlation and regression analyses respectively. Level of significance for inferential statistics was set at $p<0.05$. All the above data analysis was performed using statistical package for social sciences (SPSS) Version 22.0 software

\section{Results}

\section{Socio-demographics}

Out of the total of 286 participants recruited for the study, a total 261 had complete data at the end of the study and were used for the study analysis. From the 261 data retrieved, $162(62.1 \%)$ were female. The

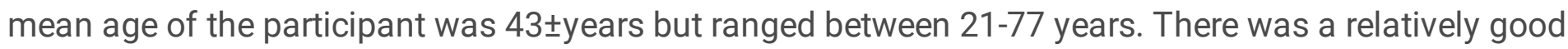
level of literacy with $84(32.2 \%)$ having secondary education and $82(31.4 \%)$ had tertiary education. Most of the participant, $165(63.2 \%)$ had stable relationship and thus were currently married. Also, most of the participants 238 (91.2\%) were staying with their families. Furthermore, a good number of the participants, 131 (50.2\%) were self-employed. However, most of them, 215 (82.4\%) earned less than N50,000 (142 Dollar) per month. Details in Table 1

\section{Clinical characteristics}

Most of the participants, 257 (98.5\%) were non-smokers and all responded to engage in one form of physical activities or the other. Most of the participants, 225 (86.2\%) do not have co-morbidity. Average years for HIV infection and being on-treatment were 5.34 and 4.75 , respectively.

At baseline, 121 (46.4\%) had viral suppression (<50cpm) while $209(80.1 \%)$ became virally suppressed after transitioning to TLD. Most of the participants were in stage WHO clinical staging-1 and had 
adherence greater than $95 \%$. However, there was statistical improvement in the other clinical parameters after commencing TLD, including WHO clinical staging ( $p=0.68)$, viral load $(p<0.001)$, mean body weight ( p $<0.001)($ Table 2).

Health Related quality of life

There was significant improvement of HRQoL scores across all 9 domains after 3 months of TLD transitioning, $(p<0.001$ in 8 domains while sexual function $p=0.015)$. Table 3 shows the mean HRQoL scores and the $p$-values

\section{Determinants/Predictors of HRQoL scores}

Using multiple linear regression analysis, predictors for overall HRQol scores include female gender ( $\nabla=$

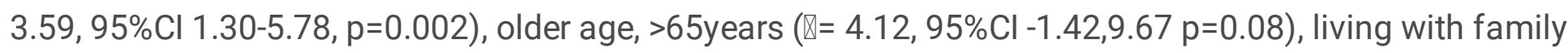

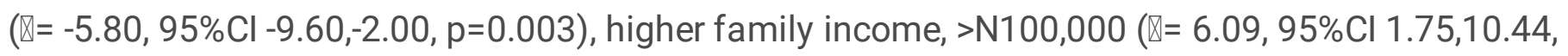

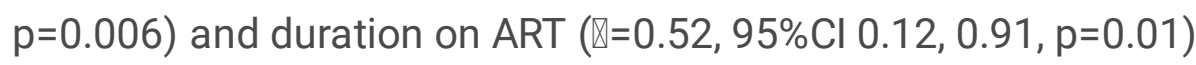

Determinants/Predictors of viral suppression

However, determinants of viral suppression using multi-variant logistic regression analysis revealed living with family (AOR=18.03, 95\% Cl 3.32-97.85, $\mathrm{p}<0.001)$, Primary education $(\mathrm{AOR}=0.16,965 \% \mathrm{Cl} 0.029,0.93$, $\mathrm{P}=0.041)$, being employed $(\mathrm{AOR}=0.16,95 \% \mathrm{Cl} 0.028,0.91, \mathrm{P}=0.008)$, income and baseline viral load ( $\mathrm{AOR}=$ $0.53,95 \% \mathrm{Cl} 0.44,0.69, \mathrm{p}<0.001)$

Table 1: Socio-Demographics of 261 HIV-positive clients receiving Tenofovir/Lamivudine/Dolutegravir from Ibrahim Badamosi Specialist Hospital, Minna, Niger state, Nigeria 2019 


\begin{tabular}{|c|c|}
\hline \multicolumn{2}{|l|}{ Gender } \\
\hline Male & 99 (37.9) \\
\hline Female & $162(62.1)$ \\
\hline \multicolumn{2}{|l|}{ Level of Education } \\
\hline No formal education & $41(15.7)$ \\
\hline Primary/Basic education & $54(20.7)$ \\
\hline Secondary education & $84(32.2)$ \\
\hline Tertiary education & $82(31.4)$ \\
\hline \multicolumn{2}{|l|}{ Marital status } \\
\hline Currently married & $165(63.2)$ \\
\hline Widowed & $50(19.2)$ \\
\hline Separate/Divorced & $27(10.3)$ \\
\hline Single & $19(7.3)$ \\
\hline \multicolumn{2}{|l|}{ Occupational status } \\
\hline House wife & $6(2.3)$ \\
\hline Student & $10(3.8)$ \\
\hline Self-employed & $131(50.2)$ \\
\hline Formally employed & $92(35.2)$ \\
\hline Retired & $22(8.4)$ \\
\hline \multicolumn{2}{|l|}{ Monthly income (Naira) } \\
\hline Less than 10,000 & $108(41.4)$ \\
\hline $10,000-50,000$ & $107(41.0)$ \\
\hline $50,000-100,000$ & $29(11.1)$ \\
\hline More than 100,000 & $17(6.5)$ \\
\hline \multicolumn{2}{|l|}{ Residential arrangement } \\
\hline Lives alone & $14(5.4)$ \\
\hline Lives with family & $238(91.2)$ \\
\hline Lives with caregiver & $9(3.4)$ \\
\hline \multicolumn{2}{|l|}{ Smoking status } \\
\hline Current smoker & $2(0.8)$ \\
\hline Non-smoker & $257(98.5)$ \\
\hline \multicolumn{2}{|l|}{ Engaged in physical activities } \\
\hline Yes & $261(100)$ \\
\hline No & 0 \\
\hline \multicolumn{2}{|l|}{ Comorbid } \\
\hline None & $225(86.2)$ \\
\hline Hypertension & $20(7.7)$ \\
\hline PUD $^{1}$ & $1(0.4)$ \\
\hline Malaria (last 4 weeks) & $2(0.8)$ \\
\hline Others & $12(4)$ \\
\hline Age, years mean (range) & $42.96(21-77)$ \\
\hline Years confirmed HIV $^{2}$ positive & $5.34(1-16)$ \\
\hline Years on $\mathrm{ART}^{3}$ & $4.75(1-10)$ \\
\hline
\end{tabular}

${ }^{1}$ Peptic ulcer Disease, ${ }^{2}$ Human immune-deficiency virus ${ }^{3}$ antiretroviral therapy

Table 2: Clinical outcomes after TLD transition of 261 patients at IBBSH Minna, Nigeria 2019 


\begin{tabular}{|c|c|c|c|}
\hline Clinical characteristics & before TLD & after TLD & P_value \\
\hline \multicolumn{4}{|l|}{ Viral load n (\%) } \\
\hline$<50 \mathrm{cpm}$ & $121(46.4 \%)$ & 209 (80.1\%) & \\
\hline$>50 \mathrm{cpm}$ & $140(53.6 \%)$ & $52(19.9 \%)$ & \\
\hline \multicolumn{4}{|l|}{$<0.001$} \\
\hline \multicolumn{4}{|l|}{ WHO clinical staging $\mathrm{n}(\%)$} \\
\hline Stage 1 & 237 (90.9\%) & 257 (98.5\%) & \\
\hline Stage 2 & $24(9.1 \%)$ & $4(1.5 \%)$ & 0.68 \\
\hline \multicolumn{4}{|l|}{ Adherence } \\
\hline Less than 95\% & 243() & $261(100 \%)$ & \\
\hline Greater than 95\% & 18() & 0 & \\
\hline $\begin{array}{l}\text { Weight, kg mean } \pm \text { sd } \\
0.001\end{array}$ & $67.51 \pm 16.48$ & $69.34 \pm 17.04$ & $<$ \\
\hline $\begin{array}{l}\text { Viral load (log) mean } \pm \text { sd } \\
<0.001\end{array}$ & $5.14 \pm 2.56$ & $3.61 \pm 44$ & \\
\hline
\end{tabular}

Table 3: Mean and standard deviation of HAT-QoL of 261 HIV patients receiving TLD, before and after 3months interval at IBBSH, Minna, Nigeria, 2019

\begin{tabular}{|c|c|c|c|}
\hline HAT-QoL ${ }^{1}$ Domains & Before TLD ${ }^{2}$ (transition) & After 3months TLD (transition) & P-values* \\
\hline $\begin{array}{l}\text { Overall function } \\
0.001\end{array}$ & $70.17 \pm 11.47$ & $94.58 \pm 10.47$ & $<$ \\
\hline $\begin{array}{l}\text { Life satisfaction } \\
<0.001\end{array}$ & $77.04 \pm 8.20$ & $95.83 \pm 8.75$ & \\
\hline $\begin{array}{l}\text { Health worries } \\
<0.001\end{array}$ & $81.59 \pm 11.87$ & $94.58 \pm 11.63$ & \\
\hline $\begin{array}{l}\text { Financial worries } \\
0.001\end{array}$ & $58.30 \pm 26.84$ & $60.14 \pm 28.37$ & $<$ \\
\hline $\begin{array}{l}\text { Medication worries } \\
0.001\end{array}$ & $71.40 \pm 11.56$ & $97.11 \pm 8.80$ & $<$ \\
\hline $\begin{array}{l}\text { HIV mastery } \\
0.001\end{array}$ & $73.04 \pm 24.86$ & $80.75 \pm 26.48$ & $<$ \\
\hline $\begin{array}{l}\text { Disclosure worries } \\
<0.001\end{array}$ & $62.47 \pm 19.42$ & $74.92 \pm 24.19$ & \\
\hline $\begin{array}{l}\text { Provider trust } \\
<0.001\end{array}$ & $82.09 \pm 11.36$ & $100 \pm 56.44$ & \\
\hline $\begin{array}{l}\text { Sexual function } \\
0.015\end{array}$ & $85.27 \pm 19.44$ & $91.46 \pm 41.10$ & \\
\hline $\begin{array}{l}\text { Overall HRQoL } \\
<0.001\end{array}$ & $72.72 \pm 7.75$ & $88.22 \pm 8.43$ & \\
\hline
\end{tabular}

${ }^{1}$ HIV/AIDS Targeted Quality of Life, ${ }^{2}$ Tenofovir/Lamivudine/Dolutegravir

Determinants of overall quality of life among patients receiving TLD at IBBSH, Minna. 2019 $(\mathrm{n}=261)$ 
overall Health related quality of life ( $\mathrm{HRQ}$ oL) scores

\begin{tabular}{|c|c|c|c|c|c|c|c|c|c|}
\hline \multirow[b]{2}{*}{$\begin{array}{l}\text { Variable } \\
\text { value }\end{array}$} & \multicolumn{3}{|c|}{ unadjusted model } & \multirow[b]{2}{*}{95 \% CI } & \multicolumn{5}{|c|}{ adjusted model } \\
\hline & $\beta$ & & $\mathrm{SE}$ & & $\mathrm{P}$ value & $\beta$ & $\mathrm{SE}$ & $95 \% \mathrm{CI}$ & $\mathrm{P}$ \\
\hline \multicolumn{10}{|l|}{ Age(yrs) } \\
\hline $18-44$ & ref & & & & & & & & \\
\hline $45-64$ & 0 & & 1.00 & $-1.83,2.1$ & 0.88 & 0.0 & 1.0 & $-2.11,2.13$ & \\
\hline \multicolumn{10}{|l|}{0.99} \\
\hline$>65$ & 4.03 & & 2.32 & $-0.54,8.5$ & 0.08 & 4.12 & 2.82 & $-1.42,9.67$ & \\
\hline \multicolumn{10}{|l|}{0.14} \\
\hline \multicolumn{10}{|l|}{ Gender } \\
\hline Male & Ref & & & & & & & & \\
\hline $\begin{array}{l}\text { Female } \\
0.002\end{array}$ & 2.75 & & 0.98 & $0.82,4.66$ & 0.005 & 3.59 & 1.16 & $1.30,5.87$ & \\
\hline \multicolumn{10}{|c|}{ Educational status } \\
\hline $\mathrm{NFE}^{\mathrm{a}}$ & Ref & & & & & & & & \\
\hline Primary & & 1.6 & & $-5.39,0.94$ & 0.17 & -2.62 & 1.61 & $-5.79,0.56$ & 0.11 \\
\hline Secondary & $\begin{array}{l}-1.70 \\
-0.95\end{array}$ & $\begin{array}{l}1.48 \\
1.48\end{array}$ & & $\begin{array}{l}-4.61,1.21 \\
-387198\end{array}$ & 0.25 & $\begin{array}{l}-2.03 \\
-165\end{array}$ & $\begin{array}{l}1.60 \\
176\end{array}$ & $-5.18,1.12$ & 0.21 \\
\hline 0.35 & & & & & & & & & \\
\hline
\end{tabular}

Occupational status

Student Ref

$\begin{array}{lrlllllll}\text { House wife } & -2.71 & 3.97 & -10.52,5.11 & 0.50 & -3.17 & 4.03 & -11.11,4.77 & 0.43 \\ \text { Retired } & \mathbf{3 . 1 8} & 2.93 & -2.59,8.94 & 0.28 & 2.33 & 3.26 & -4.10,8.76 & 0.48 \\ \text { Self-employed-0.91 } & 2.52 & -5.87,4.05 & 0.72 & 0.18 & 2.57 & -4.89,5.25 & 0.94 \\ \text { Employed } & \mathbf{1 . 2 4} & 2.56 & -3.80,6.28 & 0.63 & 2.61 & 2.69 & -2.68,7.91 & 0.33\end{array}$

Marital status

Single

Separated

Ref

0.19

$\begin{array}{lllll}\text { Married } & 0.14 & 1.87 & -3.54,3.82 & 0.94\end{array}$

$\begin{array}{llll}.17 & 0.34 & 2.36 & -4.32,5.00\end{array}$

0.89

$-0.34 \quad 2.09 \quad-4.46,3.78$

0.87

Residential

Lives with family-4.05 $1.68 \quad-7.35-0.75 \quad \mathbf{0 . 0 2}$

Income (Naira)

$<10,000 \quad$ Ref

10,000-50,000 -0.82

$1.05-2.89-1.24$

0.43

0.72

$-0.80$

$-5.80$

$1.93-9.60,-2.00$

0.003

$\begin{array}{llll}\geq 50,000-100 \mathrm{~T} & 0.57 & 1.61 & -2.60-3.74\end{array}$

0.54

$>100,000$

$4.41 \quad 2.01$

0.46-8.36

0.03

6.09

1.03

$1.16 \quad-3.08,1.48$

0.49

Viral load

$\leq 50$ copies $/ \mathrm{ml}$ Reference

$>50$ copies $/ \mathrm{ml} 0.10 \quad 0.96$

$-1,80-1.99$

0.92

$-0.92$

1.00

$-2.88,1.04$

0.36

Family size

$\leq 6 \quad$ Reference

$>6 \quad-1.660 .97 \quad-3.58-0.26$

0.09

$-0.72$

$1.06-2.80,1.38$

0.50

Comorbidity

Present (Ref)

$\begin{array}{lcccccccc}\text { Absent } & 0.79 & 1.41 & -1.98-3.57 & 0.56 & 1.47 & 1.42 & -1.34,4.28 & 0.30 \\ \operatorname{DoT}^{\mathrm{b}} \text { (yrs) } & 0.55 & 0.19 & 0.17-0.93 & \mathbf{0 . 0 0 4} & 0.52 & 0.20 & 0.12,0.91 & \mathbf{0 . 0 1}\end{array}$


${ }^{a}$ No formal education, ${ }^{b}$ Duration on therapy

Determinants of viral load after transitioning to TLD at IBBSH Minna, $n=261$ 
Viral suppression after transitioning to TLD

Univarient model

multivarient

model

Variable

OR

SE

$95 \%$ CI

$\mathrm{P}$ value

AOR SE

95\% CI P value

Age(yrs)

18-44 (ref)

$\geq 45$

$0.85 \quad 0.26 \quad 0.46,1.56$

0.61

0.68

0.34

$0.25,1.83$

0.44

Gender

Male (Ref)

Female

$0.99 \quad 0.31$

$0.53,1.84$

0.97

1.56

0.93

$0.49,4.99$

0.45

Educational status

NFE (Ref)
Primary
$0.26 \quad 0.16$
0.08-0.84
0.03
0.16
0.14
$0.029,0.93$

0.041

Secondary $\quad 0.54 \quad 0.33$

0.17-1.76 $\quad 0.31$

0.27

$0.25 \quad 0.044,1.68$

0.16

Higher

$0.36 \quad 0.21$

$0.11-1.13$

0.08

0.27

0.25

$0.037,1.73$

0.16

Occupational status

NE (Ref)

Employed $\quad 1.05 \quad 0.46$ 0.039

$0.45-2.46 \quad 0.90$

0.16

$0.14 \quad 0.028,0.91$

Marital status

Single Reference

Separated
197.230 .076

Widowed

2.13

1.77

0.36

12.3 17.41 0.77,

0.15

$0.69 \quad 0.44$

$0.19-2.43$

0.56

0.18

0.21

$0.017,1.82$

Married

$1.110 .66 \quad 0.34-3.57$

0.86

$0.27 \quad 0.27$

$0.031,2.31$

0.23

Residential

LWF

$2.83 \quad 1.30$

1.15-6.97

0.02

18.03

15.56

$3.32,97.85$

0.001

Income (Naira)

$<10 \mathrm{~T}$ (Ref)

10-50T

$0.47 \quad 0.16 \quad 0.24-0.92$

0.03

0.24

0.13

$0.085,0.69$

$\geq 50-100 \mathrm{~T}$

$1.09 \quad 0.66 \quad 0.33-3.54$

0.89

0.82

0.65

$0.17,3.87$

0.80

$>100 \mathrm{~T}$

$0.57 \quad 0.36 \quad 0.16-1.95$

0.37

0.27

$0.24 \quad 0.045,1.58$

0.15

Viral load

Log10 bvl

$<0.001$

$0.62 \quad 0.04 \quad 0.54-0.72<0.001$

0.53

0.05

$0.44,0.69$

Family size

$\leq 6 \quad$ (Ref)

$>6$

$1.14 \quad 0.36 \quad 0.61-2.12$

0.68

1.04

0.54

$0.38,2.86$

0.94 

Absent
$0.47 \quad 0.26$
0.16-1.39
0.17
1.24
0.96
$0.27,5.68$
0.78
DOT(yrs)
$0.93 \quad 0.06$
0.83-1.05
0.27
0.90
0.081
$0.75,1.07$
0.24

$\mathrm{NFE}=$ no formal education, $\mathrm{NE}=$ not employed, $\mathrm{LWF}=$ Living with family, bvl=baseline viral load DOT $=$ Duration on therapy

\section{Discussion}

This study showed improvement in HRQoL across all 9 domains using the HAT-QoL and improvement in clinical characteristics including viral suppression, adherence after 3months of transitioning to TLD. There were good mean overall HAT-Qol scores even at baseline; however statistical improvement was seen after 3months of commencing TLD. These results are not surprising has it has been widely reported that ART improves HIV client health related quality of life $(8,10,13,15,20)$. This may be due to revolutionary and efficient ART care in the facility and the implementation across the country and the world at large. Other factors like acceptability of the disease, reduced stigma and nondiscrimination $(14,15)$.

Assessment of health-related quality of life (HRQOL) is useful for determination and documentation of the patient's perceived burden of chronic disease (HIV/AIDS), the effects of the treatment, and changes in health over time, and quantification of the return on health care investment (10). Although, Biambo and colleagues studied the HRQOL of different antiretroviral regimens with TDF+FTC+LPVr having the highest score of $67.58+/-14.80$, others are much lower (14). Similarly, Oparah et al reported a high HRQoL among HIV/AIDS patients in south-east, Nigeria (13).

Furthermore, a short duration of 3 months of viral suppression seen as against one-year or longer duration to a achieve reasonable viral suppression with other combinations is in agreement of earlier findings of Rhangale and colleagues (21). similarly, Annalisa and colleagues have reported the clinical efficacy and tolerability of DTG-based regimen (22). This will prevent the possible development of resistance as seen with other combinations. This study has provided local data to further justify the use of DTG-based regimen as the most preferred first line regimen by the WHO recommendation. (1)(11). Thus, the introduction of TLD seems to be the best development to HIV care in this decade.

Similar to previous studies from Nigeria, most of the study participants were female $(15,20,23)$. This may be partly due to many entering points to HIV care such as antenatal clinics, delivery units, postnatal wards and prevention of mother to child transmission (PMTCT) involve mostly women as contained in the national guideline (24). These entry points get more women to enroll for HIV care than the male gender. Another possible explanation is the heterosexual mode of transmission is most common in 
African countries and women are more vulnerable since they are usually the receptive partner and caries higher risk of HIV transmission $(7,25)$. This is contrary to what is obtainable in western world as reported by Leonard and colleague, Brenda et al. and Viviane and colleague were the population of male surpasses that of the female $(8,26,27)$. In addition, to high prevalence of men who have sex with men (MSM) and intravenous drug user (7)

The age distribution shows more of young adults which corresponds to the sexually active age, however, a handful of older adults were also recorded. This signifies that HIV population also lives almost as long as non-HIV population. Thus, HIV infection does not really affect the average life-expectancy of individuals. In fact, HIV population is even more likely to live longer. This is because an average Nigerian (African) do not usually go for medical checkup where chronic non-communicable diseases like hypertension, diabetes, chronic kidney disease (CKD), cancers etc. can be detected and possibly manage early (28-30). Unlike HIV population that takes the advantage of the HIV disease to have access to care and screen for other diseases. These non-communicable diseases if not detected and managed early can lead to substantial reduction of individual's average life-expectancy.

Weight loss is one of the clinical parameters in HIV infection and treatment failure. However, with appropriate medication patients are able to return to normal weight or even gain $(7,31,32)$. In this study, there was significant improvement in mean body weight which may be seen as a clinical benefit of the TLD regimen. However, there is need to properly monitor patients weight gain as irrational weight gain is implicated in non-communicable diseases like hypertension, diabetes and cancers.(32)

Older age ( $>65$ years), being female gender, living alone, higher family income ( $>100,000$ naira), being employed, absence of co-morbidity, and duration on ART were predictors of higher quality of life.

However, being learned, staying as a house-wife and not employed, living with family and larger family size ( $>6$ persons) was associated with lower quality of life. Our findings with respect to being female and older age with higher quality of life contradicts the study of Brenda and colleagues in brazil and another study in china by Yunxiang and colleagues $(8,33)$. However, this is line with studies from Nigeria by Biambo et al.(23). A possible explanation is that women and older people usually get moral support from the society in this part of the world. Even at the clinics, they do enjoy favoritism and consideration which may impact positively on their quality of life.

Furthermore, the result with being employed and higher family income with better HRQoL is not surprising since this status impacts positively on individual personality and self-esteem. This in turn contributes to better quality of life.

Several researches have reported better quality of life with absence of comorbidity $(8,23,33,34)$. The burden of HIV infections with one or more other disease definitely impact negatively on patient's quality of life. In addition, the concern of medications including the cost of care may also contribute negatively to their quality of life. 
Impact of duration on ART on HRQOL has been controversial $(33,34)$. However, several researches have reported positive association between duration on ART and HRQoL $(8,23,33)$

Thus, taking note of client social demographics is essential. This help will identify clients with special counseling need which should be met appropriately.

This study revealed independent predictors of viral suppression to include; primary education, being employed; living with family; baseline viral load and family income. However, only living with family was a strong predictor. This suggests that family support and better adherence to the medication is very essential for viral suppression. This finding further implies that even basal viral load was not a strong predictor to viral suppression with this regimen. Thus a patient would definitely have viral suppression irrespective of the clients initial viral load provided the clients adhere to medication.

One of the limitations of this study is that it was a one-centre study. Thus, the outcomes cannot be extrapolated/generalized for the state/region or the country at large. However, it has provided a local data which can be leveraged on. Also, at time of the commencement of the study; most clients were already being transitioned to TLD, thus there was no avenue for direct/simultaneous comparison with other regimen. Finally, the study was for a short duration, thus the long-time effects cannot be deduced.

\section{Conclusion}

TLD is a fantastic antiretroviral combination, helping clients to achieve reasonable viral suppression within limited time interval. The combination also help improve clients HRQoL, thus clients are having viral suppression while being happy taking the medication. Age; being female, living with family, higher family income and duration on ART are major predictors of HRQoL. However, living with family is major determinant of viral suppression.

\section{Abbreviations}

TLD: Tenofivir+Lamivudine+Dolutegravir

HIV: Human Immuno-deficiency Virus

AIDS: Acquired Immuno Deficiency Syndrome

HAT-QOL: HIV/AIDS Targeted Quality of Life

PLWH: People Living with HIV

DTG: Dolutegravir

EFV: Efavirenze

ART: Anti-retroviral Therapy

Page 14/18 
IBBSH: Ibrahim Badamasi Babangida Specialist Hospital

SPSS: Statistical Package for Social Sciences

HRQOL: Health related quality of life

PMTCT: Prevention of Mother to Child Transmission

CKD: Chronic Kidney Disease

\section{Declarations}

\section{- Ethics approval and consent to participate}

Ethical approval was sought from the IBBSH human research and ethics committee. Clearance certificate number M201902. All participants gave written informed consent prior to enrollment into the study.

\section{Consent for publication}

Not applicable

\section{- Availability of data and materials}

The datasets used and/or analyzed in this study are available from the corresponding author on reasonable request.

\section{- Competing interests}

The authors declare that they have no competing interests

\section{- Funding}

Neither funding nor grant was received for this research

\section{- Authors' contributions}

UDM (Principal investigator): proposed, designed and implemented the study, did the part of the analysis and write-up. BW, SM and NU: Made substantial contributions to conception and design of the proposal, analysis and interpretation of data critically edit and approved the final manuscript. NU, AMH and UNM: Made significant contributions in design, interpretation of data, revising and approved the final manuscript. BW, UNM and AMH: Participated sufficiently in analysis and interpretation of data, involved in drafting the manuscript, critically edited and approved the final manuscript. However, all authors read and approved the final manuscript.

\section{- Acknowledgements}


The authors wish to appreciate all the participants that consented and made this research possible. The authors also wish to appreciate the USAID/MSH for provided free HIV care in Nigeria and the world at large.

\section{References}

1. World Health Organization. Dolutegravir (DTG) and the fixed dose combination (FDC) of tenofovir/lamivudine/dolutegravir (TLD). Brief note [Internet]. 2018;2:1-10. Available from: https://www.who.int/hiv/pub/arv/DTG-TLD-arv_briefing_2018.pdf

2. FMOH. Rapid Advice: recommendation of first line antiretroviral therapy in Nigeria. Abuja; 2018.

3. WHO. UPDATE OF RECOMMENDATIONS ON FIRST-AND SECOND-LINE ANTIRETROVIRAL REGIMENS. 2019.

4. Indicator A, Survey I, Zone NC, Hiv H, Ministry F, Agency N, et al. 1 naiis preliminary findings, north central zone -march 2019. 2019;(December 2018):2-5.

5. Carter AR, Biehl MH, Douwes-schultz D, Arora M. Global , regional , and national incidence, prevalence, and mortality of HIV , 1980 - 2017, and forecasts to 2030 , for 195 countries and territories: a systematic analysis for the Global Burden of Diseases , Injuries , and Risk Factors Study 2017. 2019;(August).

6. UNAID. The 2019 Report on the global AID epidemic. In Geneva: UNAIDS; 2019.

7. Sheena Castelino, Alison Grant KC. HIV Infection. In: Cate Whittlea KH, editor. Clinical Pharmacy and Therapeutics. 6th ed. china: Elsevier; 2019. p. 688-725.

8. Soares B, Paula A, Lins-kusterer L, Rodriguez I, Brites C. Original article Changes health-related quality of life in HIV-infected patients following initiation of antiretroviral therapy: a longitudinal study. 2019;3(4):211-7.

9. Call SA, Klapow JC, Stewart KE, Westfall AO, Mallinger AP, Demasi RA. Health-related quality of life and virologic outcomes in an HIV clinic. 2001;977-85.

10. Mafirakureva N, Dzingirai B, Postma MJ, Hulst M Van, Khoza S. Health-related quality of life in HIV / AIDS patients on antiretroviral therapy at a tertiary care facility in Zimbabwe. AIDS Care [Internet]. 2016;28(7):904-12. Available from: http://dx.doi.org/10.1080/09540121.2016.1173639

11. Biraguma J, Mutimura E, Frantz JM. Health-related quality of life and associated factors in adults living with hiv in rwanda. Sahara J. 2018;15(1).

12. Surur AS, Teni FS, Wale W, Ayalew Y, Tesfaye B. Health related quality of life of HIV/AIDS patients on highly active anti-retroviral therapy at a university referral hospital in Ethiopia. BMC Health Serv Res. 2017;17(1).

13. Oparah AC, Soni JS, Arinze HI, Chiazor IE. Patient-Reported Quality of Life During Antiretroviral Therapy in a Nigerian Hospital. 2013;2:254-8.

14. Biambo A al, Adibe MO, Liman HM, Ukwe C V. Health-related quality of life of HIV-infected patients taking different antiretroviral regimens at a tertiary healthcare facility in northern Nigeria. Trop $\mathrm{J}$ 
Pharm Res. 2018;17(3):549-57.

15. Suleiman BA, Yahaya M, Olaniyan FA, Sule AG, Sufiyan MB. Determinants of health-related quality of life among human immunodeficiency virus positive ( HIV-positive ) patients at Ahmadu Bello University teaching hospital , Zaria , Nigeria- 2015. 2020;1-9.

16. Akinboro AO, Omolola Akinyemi S, Olaitan PB, Raji AA, Popoola AA, Awoyemi OR, et al. Quality of life of Nigerians living with human immunodeficiency virus.

17. Fatiregun A. A., Mofolorunsho K. C. OKG. Quality of Life of People Living with HIV/AIDS in Kogi State, Nigeria. 2009;11(1):21-7.

18. Raosoft. Sample Size Calculator. 2004.

19. Holmes WC SJ. A new HIV/AIDS-targeted quality of life (HAT-QoL) instrument: development, reliability, and validity. 1998. p. 138-154.

20. Yaya I, Djalogue L, Patassi AA, Landoh DE, Assindo A, Nambiema A, et al. Health - related quality of life among people living with HIV / AIDS in Togo: individuals and contextual effects. BMC Res Notes [Internet]. 2019;1-6. Available from: https://doi.org/10.1186/s13104-019-4171-x

21. Al R et. Integrase inhibitors in late pregnancy and rapid HIV viral load reduction. Am J Obstet Gynaecol. 2016;1-7.

22. Mondi A, Cozzi-lepri A, Tavelli A, Rusconi S, Vichi F, Ceccherini-silberstein F, et al. Effectiveness of dolutegravir-based regimens as either first-line or switch antiretroviral therapy: data from the Icona cohort. 2019;(July 2018):1-10.

23. Biambo et alRights. HEALTH RELATED QUALITY OF LIFE AND ITS PREDICTORS IN HIV-INFECTED PATIENTS RECEIVING ANTIRETROVIRAL THERAPY AT A NIGERIAN TERTIARY HEALTHCARE FACILITY. Niger J Pharm. 2018;17(1):57-68.

24. Federal Ministry of Health N. NATIONAL GUIDELINES FOR HIV PREVENTION TREATMENT AND CARE NATIONAL AIDS AND STI' s CONTROL. Abuja FM of H, editor. Abuja: Federal Ministry of Health Abuja Nigeria; 2016. 17-21 p.

25. Peter L. Aanderson TNK and CVF. Human Immunodeficiency Virus Infection. In: Joseph T. Dipiro, Robert L. Talbert, Gary C. Yee, Garry R. Matzke, Barbara G. Weks MPL, editor. Pharmacotherapy; A Pathophysiology approach. seventh. Chicago: Mc Graw Hill Medical; 2008. p. 2065-85.

26. Emuren L, Welles S, Evans AA, Polansky M, Okulicz F, Macalino G, et al. Health-related quality of life among military HIV patients on antiretroviral therapy. 2017;3:1-17.

27. Lima VD, Nosyk B, Wood E, Kozai T, Zhang W, Chan K, et al. HHS Public Access. 2015;26(12):1491500 .

28. Usman SO, Suleiman A, Isola IN, Ojogbede A. Periodic medical check-up among residents of three Nigerian South-western o RJINAL ARAŞTIRMA Periodic medical check-up among residents of three Nigerian South- western States Corresponding Author: Saheed Opeyemi Usman. 2017;(September 2016). 
29. Ojong IN, Nsemo AD, Aji P. Routine Medical Checkup Knowledge , Attitude and Practice among Health Care Workers in a Tertiary Health Facility in Calabar, Cross River State, Nigeria. 2020;12(8):27-37.

30. Ofoli JNT, Ashau-oladipo T, Hati SS, Ati L, Ede V. Preventive healthcare uptake in private hospitals in Nigeria: a cross-sectional survey ( Nisa premier hospital ). 2020;1-10.

31. Preez NF, Peltzer $Æ$ EK. HIV Symptoms and Health-Related Quality of Life Prior to Initiation of HAART in a Sample of HIV-Positive South Africans. 2010;1437-47.

32. Kumar S, Samaras K. The Impact of Weight Gain During HIV Treatment on Risk of Pre-diabetes, Diabetes Mellitus , Cardiovascular Disease, and Mortality. 2018;9(November):1-14.

33. Huang Y, Luo D, Chen X, Zhang D, Wang M, Qiu Y, et al. Changes and determinants of health-related quality of life among people newly diagnosed with HIV in China: a 1-year follow-up study. Qual Life Res. 2019;28(1).

34. Ghiasvand H, Waye KM, Noroozi M, Harouni GG. Clinical determinants associated with quality of life for people who live with HIV / AIDS: a Meta-analysis. 2019;1-11. 